\title{
Athelia (Sclerotium) rolfsii in Allium sativum: potential biocontrol agents and their effects on plant metabolites
}

\author{
VYTÓRIA P. CAVALCANTI ${ }^{1}$, NEILTON A.F. ARAÚJO ${ }^{1}$, KÁTIA R.F. SCHWAN- \\ ESTRADA ${ }^{2}$, MOACIR PASQUAL ${ }^{1}$ and JOYCE DÓRIA ${ }^{1}$ \\ ${ }^{1}$ Departamento de Agricultura, Universidade Federal de Lavras/UFLA, Câmpus \\ Universitário, Caixa Postal 3037, 37200-000 Lavras, MG, Brazil \\ ${ }^{2}$ Departamento de Agronomia, Universidade Estadual de Maringá/UEM, Câmpus \\ Universitário, Av. Colombo, 5790, 87020-220 Maringá, PR, Brazil
}

Manuscript received on March 1, 2018; accepted for publication on August 1, 2018

\begin{abstract}
Garlic (Allium sativum L.) plays an important role in popular culture due to its dietary and medicinal uses. It is also used to produce a wide range of pharmacologically interesting molecules. Several pathogens affect garlic plants, especially Athelia (Sclerotium) rolfsii, a fungus that is widespread and causes large economic losses. It causes direct damage to crops and leads to plant stress, which induces secondary metabolite production in plants. The use of microorganisms as biocontrol agents may induce the production of beneficial metabolites in plants that will protect it and promote resistance to pathogen attack. In addition to suppressing disease, biological control agents may have elicitor effects that could induce an increase in the production of useful bioactive secondary metabolites in plants, some of which may be of pharmacological interest. Therefore, the search for new biological control agents should also consider their potential as elicitor agents. This paper presents an analysis of the biological control of Athelia (Sclerotium) rolfsii by antagonistic microrganisms, the potential of yeasts and bacteria of the genus Bacillus for the biocontrol of phytopathogens, microrganisms influence in nutritional and bioactive compounds content of interest to the pharmaceutical industry.
\end{abstract}

Key words: biological control, phytopathogen, yeast, Bacillus spp., elicitation, garlic.

\section{INTRODUCTION}

Garlic (Allium sativum L.) is a member of the Alliaceae family. It is cultivated all over world and demand for it is high due to its medicinal properties. Brazilian production reached 126.157 tons in 2017, of which, 84.131 tons were exported (Agrianual 2018). Garlic contains high levels of starch and

Correspondence to: Joyce Dória

E-mail: joyce.soares@dag.ufla.br aromatic compounds, which means that it has a high flavor and medicinal value. It is also used as a herbal medicine due to its diverse pharmacological properties (Souza and Macêdo 2009, Resende et al. 2016)

The pharmacological properties of garlic are related to the presence of secondary metabolites, such as organosulfur compounds, which are responsible for its strong, characteristic odor. These compounds protect the plant against insects and 
phytopathogens (Kusano et al. 2016). Allicin is the main component responsible for the antibiotic, antiviral, and antifungal characteristics of the plant (Curtis et al. 2004, Ota et al. 2010, Borlinghaus et al. 2014). Phenolic compound contents are also high in garlic, especially the flavonoids: quercetin, apigenin, and myricetin (Lanzotti 2006), which play a role in plant resistance to pathogens (Lattanzio et al. 2006).

Garlic production can be affected by several phytopathogens, especially Athelia (Sclerotium) rolfsii, which causes white rot. In particular $A$. rolfsii causes bulb rotting, which means that it is an important disease that should be investigated further because it causes substantial economic production losses around the world. Garlic and onion losses can reach $65 \%$ in climate temperate countries, such as the United Kingdom and Canada, whereas the losses can be up to $100 \%$ in countries with a tropical climate, such as Brazil and Mexico (Kwon 2010, El-Nagar et al. 2013, Domingos et al. 2015). Therefore, there is a need to identify new methods that can be used to control phytopathogens, preferably ones that reduce the need to use pesticides and emphasize the use of biological control and resistance induction as efficient complementary measures.

Phytopathogen attacks influence secondary metabolite production in plants. The use of yeasts and bacteria to induce resistance also shares this principle because the plant starts to produce secondary metabolites that will protect it from pathogen attack. Therefore, we need to know about any alterations in the plant secondary metabolite contents and whether these are of biological and economic interest before yeasts and Bacillus spp. are used to biologically control $A$. rolfsii in garlic (Allium sativum L.). The aim of this study was to investigate whether yeast strains and Bacillus spp. could biologically control $A$. rolfsii in garlic when applied on a commercial scale and investigate their effects on plant metabolites.

\section{GARLIC PRODUCTION AND Athelia (Sclerotium) rolfsii}

Garlic (Allium sativum L.) is a species that originally came from Asia and belongs to the Alliaceae family (Souza and Macêdo 2009, Resende et al. 2016). Brazil is a major importer of garlic "in natura", and imports reached about 17,000 tons in 2016, corresponding to $\$ 26.9$ million. However, its production in Brazil during the same year was approximately 130,407 tons over 11,334 ha. The average yield was $11.5 \mathrm{t} / \mathrm{ha}$, and $274 \mathrm{~kg}$ (valued at $\$ 829,000$ ) were exported between January and August, 2016 (Morozini et al. 2005, Fagundes 2016, IBGE 2016, Marques 2017). Furthermore, Brazil exported 7.0 tons of garlic powder, valued at \$18.900, between January and August, 2016 (Fagundes 2016).

Garlic is a medicinal plant that has been used since ancient times to treat various diseases. Its main biological activities are fighting infections, lowering blood pressure and cholesterol, and cancer prevention. It is also has antibiotic, antifungal, antiviral, anthelmintic, light antihypertensive, antidiabetic, antioxidant, hepatoprotective, antiinflammatory, and wound healing properties (Gómez and Sánchez-Muniz 2000, Yeh and Liu 2001, Corzo-Martínez et al. 2007, Londhe et al. 2011, Borlinghaus et al. 2014).

The medicinal, dietary, and pest and disease control characteristics (Slusarenko et al. 2008) shown by garlic are due to its phytochemical composition. In particular, allicin and thiosulfates are responsible for a large number of the garlic medicinal properties, such as its antibiotic, antiviral and anti-cancer, antioxidant, hypotensive, reduction of endogenous cholesterol synthesis, and inhibition of platelet aggregation properties (Borlinghaus et al. 2014). Aliin, which has hypotensive and hypoglycemic properties (Gómez and SánchezMuniz 2000); ajoene, which is used to prevent clots, and has anti-inflammatory, vasodilator, 
hypotensive, and antibiotic effects (Corzo-Martínez et al. 2007); S-allyl cysteine, which is involved in the hypocholesterolemic properties of garlic (Yeh and Liu 2001); adenosine, which is a vasodilator, and has hypotensive and myorelaxant properties (Gómez and Sánchez-Muniz 2000); fructan, which is involved in the cardioprotective activity shown by garlic (Gómez and Sánchez-Muniz 2000); inulin, a reserve polysaccharide that acts as dietary fiber and a prebiotic (Dalonso et al. 2009); vitamins A, B, and C; proteins; and minerals, etc. (Ota et al. 2010) are mainly found in the garlic cloves. It is the part of the plant that is most often used to extract compounds because it is where the active constituent levels are greatest (Chagas et al. 2012).

Phytopathogen occurrence can reduce product quality. A. rolfsii is mainly a soil borne pathogen. It causes diseases in more than 500 species of mono and eudycotyledons, and is represented in 100 families (Kwon 2010, El-Nagar et al. 2013). It is polyphagous and can lead to rots in the roots, young plants, and seeds; and damages seedlings, leaves, and fruits (Faria et al. 2009). It is a fast-growing phytopathogen that produces persistent sclerotia, which makes it a difficult-to-control fungus that has been responsible large economic losses in the past (Ali et al. 2017). El-Nagar et al. (2013) observed virulence in three isolates of $A$. rolfsii, which had infection rates that varied from 56.7 to $73.3 \%$ in pre- and post-emergence garlic seeds. In the field, its incidence on garlic and onion crops seems to be highly correlated with sclerotia density in the soil during planting. The incidence of white rot caused by Sclerotium cepivorum is also related to sclerotia density (Domingos et al. 2015).

Product quality has an extremely important effect on garlic commercialization. Therefore, the control of pests and diseases throughout the production process is fundamental because they can reduce both garlic yield and quality (Moura et al. 2013).

\section{BIOLOGICAL CONTROL OF Athelia (Sclerotium) rolfsii}

Athelia (Sclerotium) rolfsii cannot be controlled by a single cultural or chemical method, such as the use of fungicides or cultural rotation with resistant plants (de Sousa and Blum 2013). Therefore, integrated pest management is important and one complimentary tool that can be used is biological control. Its advantages are that it is a safe, efficient, and economically viable method that causes less pollution than agrochemicals. Furthermore, it can be used in organic agriculture systems (Bettiol and Morandi 2009).

Isaias et al. (2014) verified the antagonistic effect exerted by fungi of the genus Trichoderma against $A$. rolfsii. They investigated this antagonism using a paired cultures test and by measuring the reduction in mycelial growth due to volatile, nonvolatile and non-volatile thermostable metabolites. The results showed that the secondary metabolites produced by the antagonists in the genus Trichoderma had a significant effect on $A$. rolfsii growth (Table I).

An important action mechanism underlying the antagonistic microorganism effects on $A$. rolfsii is the production of hydrolytic enzymes that degrade phytopathogenic cells and, consequently, suppress their development through mycoparasitism of sclerodes and hyphae. This mechanism has been shown to be affective against actinobacteria in the genus Streptomyces (Li et al. 2017, Thampi and Bhai 2017). Mycoparasitism is one of the main mechanisms used by Trichoderma isolates to control $A$. rolfsii because they can produce chitinase and $\beta$-1,3-glucanase, which are involved in mycoparasitism (Hirpara et al. 2017, Rao et al. 2015). Bacteria in the genera Pseudomonas and Bacillus also produce chitinase, among other lytic enzymes. These enzymes can break down polymeric compounds, such as chitin, proteins, cellulose, and hemicellulose. Their main effect is 
to degrade the cell wall of the pathogen (Abou-Aly et al. 2015, Saritha et al. 2015, Janahiraman et al. 2016).

Antibiosis is another action mechanism that been shown to control phytopathogens. Bacillus amyloliquefaciens has biosurfactant activity and reduces the surface tension associated with the production of the lipopeptide iturin A. It shows $77.7 \%$ inhibition of the phytopathogen and has potential antifungal activity (Kumar et al. 2015). Bacillus subtilis also seems to use this mechanism against Rhizoctonia bataticola and $R$. solani. Electron microscopy images show that it reduces fungal growth and alters the morphology of the hyphae and sclerotia (Mnif et al. 2016).

The Agrobacterium and Kluyvera genotypes have been shown to promote the biocontrol of $A$. rolfsii by competing for iron. This limits various activities in the phytopathogen isolates and the nutritional composition of the growth medium (Pelzer et al. 2011). Bacillus isolates have also been shown to efficiently control $A$. rolfsii using antibiosis. They release extracellular compounds into the rhizosphere, and produce antimicrobial substances and plant hormones. These suppress plant diseases, promote growth, and improve plant nutrient absorption from the soil (Suneeta et al. 2016).

Hydrogen cyanide (cyanogenesis) and siderophore production may also inhibit pathogens. These methods are thought to be used by bacteria in the genera Pseudomonas and Bacillus to control A. rolfsii. Furthermore, they are organic compounds that could potentially replace pesticides (Abou-Aly et al. 2015, Kotasthane et al. 2017).

Mycorrhiza associated bacteria (MAB) help promote plant growth through the production of known and unknown metabolites, solubilization of nutrients in the soil, and suppression of pathogens. A previous study showed that Pseudomonas putida, in association with Glomus mosseae, could suppress $A$. rolfsii, using several potential control mechanisms (Saritha et al. 2015) (Table I). Saritha et al. (2015) investigated whether MABs could potentially be used for biocontrol and to manage soil-transmitted phytopathogens under field conditions.

The biocontrol of $A$. rolfsii has been studied using several microorganisms and crop types that are attacked by this pathogen, such as fruit, leguminous, tuberous, and herbaceous crops (Table I). The fungi and bacteria that have been tested include fungi in the genus Trichoderma (de Sousa and Blum 2013, Isaias et al. 2014, Rao et al. 2015, Dania et al. 2016, Hirpara et al. 2016, 2017, Pacheco et al. 2016, Islam et al. 2017), Pseudomonas bacteria (Saritha et al. 2015, Vaja et al. 2016, Kotasthane et al. 2017), and bacteria in the genus Bacillus (Abou-Aly et al. 2015, Kumar et al. 2015, Suneeta et al. 2016, Figueredo et al. 2017).

Further studies on biologically controlling $A$. rolfsii infection of Allium sativum are necessary because there have been few previous studies on this subject and they have only investigated Trichoderma (Table I). Yeasts and Bacillus spp. may be highly suitable biological control agents because Bacillus spp. have already been used to successfully control $A$. rolfsii (Table I) in other plants. Furthermore, yeasts have been shown to biologically control other phytopathogens using several different action mechanisms. However, the use of certain microorganisms for biological control could be restricted because the potentially useful microorganisms might not be able to adapt to different environmental and cultivation conditions. Selection pressure may also reduce their effectiveness. For these reasons, interest in identifying new alternatives for the biological control of $A$. rolfsii in Allium sativum is increasing. Future research should expand the number of biocontrol options and reduce the potential breakdown of existing control methods. 
TABLE I

Antagonistic microrganisms in Athelia (Sclerotium) rolfsii control.

\begin{tabular}{|c|c|c|c|}
\hline Culture & Antagonist & Action Mechanism & Reference \\
\hline In vitro & $\begin{array}{l}\text { Trichoderma virens, } \\
\text { T. koningii, } \\
\text { T. viride and } \\
\text { T. harzianum }\end{array}$ & Mycoparasitism & $\begin{array}{l}\text { Hirpara et al. } \\
\qquad(2017)\end{array}$ \\
\hline $\begin{array}{c}\text { Solanum } \\
\text { lycopersicum }\end{array}$ & $\begin{array}{l}\text { Trichoderma harzianum, } \\
\text { T. virens and } \\
\text { T. asperellum }\end{array}$ & - & $\begin{array}{l}\text { Islam et al. } \\
\quad(2017)\end{array}$ \\
\hline In vitro & $\begin{array}{l}\text { Trichoderma virens and } \\
\text { T. koningii }\end{array}$ & Mycoparasitism and antibiosis & $\begin{array}{l}\text { Hirpara et al. } \\
\quad(2016)\end{array}$ \\
\hline Phaseolus vulgaris & $\begin{array}{l}\text { Trichoderma asperellum, } \\
\text { T. harzianum, } \\
\text { T. longibrachiatum and } \\
\text { T. reesei }\end{array}$ & - & $\begin{array}{l}\text { Pacheco et al. } \\
\qquad(2016)\end{array}$ \\
\hline $\begin{array}{l}\text { Amorphophallus } \\
\text { paeonifolius }\end{array}$ & $\begin{array}{c}\text { Trichoderma harzianum and } \\
\text { T. asperellum }\end{array}$ & $\begin{array}{l}\text { Mycoparasitism and antibiosis (diffusible } \\
\text { metabolites) }\end{array}$ & $\begin{array}{l}\text { John et al. } \\
\quad(2015)\end{array}$ \\
\hline Nicotiana tabacum & Trichoderma Isolates & $\begin{array}{l}\text { Mycoparasitism, antibiosis (volatile and diffusible } \\
\text { metabolites), cyanogenesis and siderophores } \\
\text { production }\end{array}$ & $\begin{array}{l}\text { Rao et al. } \\
(2015)\end{array}$ \\
\hline Allium sativum & Trichoderma harzianum & - & $\begin{array}{l}\text { de Sousa and } \\
\text { Blum (2013) }\end{array}$ \\
\hline In vitro & Trichoderma & Antibiosis (volatile and diffusible metabolites) & $\begin{array}{c}\text { Isaias et al. } \\
(2014)\end{array}$ \\
\hline $\begin{array}{l}\text { Dioscorea rotundata, } \\
\text { D. cayenensis, } D . \\
\text { alata and } D . \\
\text { dumetorum }\end{array}$ & $\begin{array}{l}\text { Trichoderma asperellum, } \\
\text { T. longibrachiatum, } \\
\text { Bacillus subtilis and } \\
\text { Pseudomonas fluorescens }\end{array}$ & - & $\begin{array}{l}\text { Dania et al. } \\
\quad(2016)\end{array}$ \\
\hline Cicer arietinum & Pseudomonas Isolates & Siderophores and cyanogenesis production & $\begin{array}{l}\text { Kotasthane et } \\
\text { al. (2017) }\end{array}$ \\
\hline In vitro & Pseudomonas aeruginosa & Siderophores production & $\begin{array}{l}\text { Vaja et al. } \\
(2016)\end{array}$ \\
\hline In vitro & $\begin{array}{l}\text { Pseudomonas putida associated } \\
\text { to Glomus mosseae (bacterium } \\
\text { associated with mycorrhiza) }\end{array}$ & $\begin{array}{c}\text { Siderophores production, ammonia, cyanogenesis, } \\
\text { protease, chitinase, urease and ACC deaminase, } \\
\text { antibiosis }\end{array}$ & $\begin{array}{l}\text { Saritha et al. } \\
\qquad(2015)\end{array}$ \\
\hline In vitro & $\begin{array}{l}\text { Pseudomonas fluorescens and } \\
\text { Bacillus subtilis }\end{array}$ & $\begin{array}{l}\text { Activity chitinase, production of siderophores, } \\
\text { cyanogenesis, antibiosis (volatile metabolites) }\end{array}$ & $\begin{array}{l}\text { Abou-Aly et } \\
\text { al. (2015) }\end{array}$ \\
\hline $\begin{array}{l}\text { Lycopersicon } \\
\text { esculentum }\end{array}$ & $\begin{array}{l}\text { Delftia lacustris, } \\
\text { Bacillus subtilis and } \\
\quad \text { B. cereus }\end{array}$ & $\begin{array}{l}\text { Increased production of } \beta \text {-1,3-glucanase, } \\
\text { chitinase, phenylalanine ammonia lyase, } \\
\text { peroxidase, polyphenol oxidase and catalase and } \\
\text { induction of systemic resistance }\end{array}$ & $\begin{array}{l}\text { Janahiraman et } \\
\text { al. (2016) }\end{array}$ \\
\hline $\begin{array}{l}\text { Gerbera jamesonii } \\
\text { (gerbera) }\end{array}$ & Bacillus Isolates & Antibiosis & $\begin{array}{l}\text { Suneeta et al. } \\
\qquad(2016)\end{array}$ \\
\hline In vitro & Bacillus amyloliquefaciens & Biosurfactants and iturin A production & $\begin{array}{l}\text { Kumar et al. } \\
\text { (2015) }\end{array}$ \\
\hline $\begin{array}{l}\text { Arachis hypogaea } \\
\text { (peanut) }\end{array}$ & Bacillus sp. & Systemic resistance induction (SRI) & $\begin{array}{l}\text { Figueredo et } \\
\text { al. (2017) }\end{array}$ \\
\hline
\end{tabular}


TABLE I (continuation)

\begin{tabular}{cccc}
\hline Culture & Antagonist & Action Mechanism & Reference \\
\hline \multirow{2}{*}{ In vitro } & $\begin{array}{c}\text { Streptomyces globisporus, } \\
\text { S. flavotricini, } \\
\text { S. pactum and } \\
\text { S. senoensis }\end{array}$ & Antibiosis and mycoparasitism & Li et al. (2017) \\
\hline $\begin{array}{c}\text { Piper nigrum (black } \\
\text { pepper) }\end{array}$ & Streptomyces sp. & Mycoparasitism, production of indoleacetic acid & Thampi and \\
In vitro & Rhizobacteria of genus & Bhai (2017) \\
\hline
\end{tabular}

BIOLOGICAL CONTROL OF PHYTOPATHOGENS BY YEAST AND Bacillus spp.

Antagonistic yeasts are able colonize rapidly and grow in superficial lesions. Their faster growth rate means that they can inhibit the development of phytopathogenic fungi by successfully competing for nutrients and space. Yeasts are unicellular organisms, which mean they have a faster growth rate than multicellular phytopathogenic fungi, such as molds (Úbeda et al. 2014). In vivo tests have shown that Pichia membraneefaciens and Kloeckera apiculata significantly reduced (76.0\% and $65.8 \%$, respectively) the incidence of Monilinia fructicola rot in plums by competing with the phytopathogen for nutrients and space. They may also have produced volatile organic compounds with antifungal action (antibiosis) that caused mycoparasitism through the production of hydrolytic enzymes, such as chitinase and $\beta-1,3-$ glucanase (Zhang et al. 2017).

Yeasts can also induce resistance in plants. Suspensions of Candida oleophila cells in grapefruit peel tissue increased ethylene biosynthesis and phenylalanine ammonia lyase activity. Candida oleophila inoculation also led to the accumulation of phytoalexins and increased levels of chitinase and protein $\beta$-1,3-endoglucanase (Droby et al. 2002).

Sun et al. (2018) applied preparations containing cell walls from the yeast $R$ hodosporidium paludigenum to pear fruits to investigate whether it had any activity against blue mold (Penicillium expansum). There was a reduction in disease incidence and lesion diameter at all tested concentrations. They also observed resistance induction in the fruits because in vivo spore germination decreased when the time difference between treatment with the cell wall preparation and inoculation with the phytopathogen was extended. For example there was $70 \%$ spore germination when inoculation took place at 2 hours after the cell wall treatment, but less than $10 \%$ spore germination when the inoculation time was 24 hours after the cell wall treatment. Induction of resistance caused a significant increase in the activity of defenserelated enzymes ( $\beta$-1,3-glucanase and chitinase) and the expression of specific protein genes related to pathogenesis (PR1-like, endoGLU9, endoCHIlike, and PR4).

The induction of a defense response in tomato by Aureobasidium pullulans increased $\beta-1,3$ glucanase activity and led to the production of bioactive volatile and non-volatile metabolites that were capable of inhibiting colony growth and causing morphological changes to the hyphae of Phytophthora infestans (Di Francesco et al. 2017).

Chi et al. (2015) reported that the yeast Pichia kudriavzevii formed a biofilm. Biofilms are morphologically more resistant to high temperatures and oxidative stress, and can be involved in biological control activity. Klein and Kupper (2018) reported a positive correlation 
between an increase in antagonistic activity and a rise in biofilm production. They emphasized that biofilm formation was an important biological control mechanism because the antagonist rapidly colonized the lesions and the film protected the plant against attack from phytopathogens.

Úbeda et al. (2014) suggested that the species Pichia kudriavzevii was a good candidate for the biocontrol and bioremediation of wastewater contaminated by heavy metals because it inhibited the molds: Phaeomoniella chlamydospora, Neofusicoccum parvum, Diplodia seriata, Phaeoacremonium aleophilum, and Aspergillus niger, and accumulated the highest proportion of the three tested metals: $\mathrm{Cr}$ (VI), Pb (II), and Cd (II). Kupper et al. (2013) evaluated whether Saccharomyces cerevisiae and Bacillus subtilis could be used to control Penicillium digitatum. They found that a large number of the bacterial isolates and all the yeast isolates were able to reduce P. digitatum mycelial growth. They also found that one of the bacterial isolates could inhibit conidial germination $(72 \%)$ and that two $S$. cerevisiae isolates produced the best inhibition results (78 and $85.7 \%$ inhibition).

Bacillus is a genus of great interest to agriculture because some of its members promote plant growth and have a wide range of antagonistic mechanisms, which means that they are able to circumvent phytopathogen defenses (Lanna Filho et al. 2010). Bacteria in this genus colonize the roots and form microcolonies or biofilms at preferred root exudation sites. They act as rhizospheric agents that are capable of degrading substrates derived from fauna, flora, and compounds of organic origin. Furthermore, they promote nitrogen fixation and phosphate solubilization, which increases plant growth (Chen et al. 2007, Choudhary and Johri 2009, Kumar et al. 2012, Corrales-Ramírez et al. 2017). They also produce antipathogenic substances and/or induce resistance mechanisms in the plant (Chaurasia et al. 2005, Choudhary and Johri 2009,
Huang et al. 2012, Kumar et al. 2012, Gond et al. 2015). In addition to these two biocontrol benefits, the genus Bacillus is also physiologically diverse due to the formation of endospores that allow it to survive for long periods in many different environments (Lanna Filho et al. 2010, Corrales -Ramírez et al. 2017).

Antagonistic microorganisms are already commercially available, such as the yeasts Candida oleophila and Cryptococcus albidus, and two strains of the bacterium Pseudomonas syringae, which are sold under the trade names Aspire (Ecogen Inc., Langhorn, PA, USA), YieldPlus (Anchor Yeast, Cape City, South Africa), and BIOSAVE-110 and BIOSAVE-111 (EcoScience, Orlando, FL, USA), respectively (Droby et al. 2002).

There are also several products on the market that contain commercial strains of bacteria from the genus Bacillus and they have been used to biologically control phytopathogens. For example there are Kodiak ${ }^{\circledR}$ and YieldShield ${ }^{\circledR}$ developed by the company Gustafson that contain strains of Bacillus subtilis and B. pumilus, respectively. Gustafson also developed BioYield ${ }^{\circledR}$, which is a blend of B. subtilis and B. amyloliquefaciens strains. The products Rhapsody ${ }^{\circledR}$, Sonata $\AA$, and Ballad ${ }^{\circledR}$ contain different strains of $B$. pumilus and are made by AgraQuest. There are also other products available that contain $B$. subtilis, such as Subtilex ${ }^{\circledR}$ (Becker Underwood), Serenade ${ }^{\circledR}$ (AgraQuest), and BioPro ${ }^{\circledR}$ (Andermatt Bioc.) (Bettiol and Morandi 2009).

\section{INFLUENCE OF MICROORGANISMS ON PHYTOCHEMICAL COMPOSITION}

One of the strategies used to increase the production of secondary metabolites that are of commercial interest is to create biotic and abiotic stress conditions (Jimenez-Garcia et al. 2013) because the plants then produce several secondary metabolites related to different stress adaptations (Shetty and Wahlqvist 
2004). Phytoalexins are secondary metabolites produced by plants in response to stress, attack by microorganisms, and/or elicitor treatments. They usually have an antimicrobial action and could potentially be exploited as nutritional products that can be added to foods to give them antioxidant, anti-inflammatory, hypocholesterolemic, and anticancer activities (Boue et al. 2009).

Phytopathogen attacks cause plant stress and may induce the production of secondary defense metabolites. Pontin et al. (2015) found that garlic produced terpenes. These have antifungal properties and are produced in response to Sclerotium cepivorum infection. In addition, elicitor, biotic, or abiotic treatments can also be used. These treatments promote the induction of plant resistance against phytopathogens, which can lead to an increase in the production of certain compounds of interest by the plant (Baenas et al. 2014).

Resveratrol is a polyphenol produced by grapes and other plant species. It has antioxidant and chemopreventive activities against various types of cancer and cardiovascular diseases, which means it could be used to improve human health (Shankar et al. 2007). Resveratrol is a phytoalexin produced by grapes when they are under stress, such as excess UV radiation and phytopathogen attack. Jeandet et al. (1995) observed that the resveratrol content in grapes (Vitis vinifera) increased when they were attacked by Botrytis cinerea under natural conditions (Table II).

Yeasts are single-celled fungi that are part of the epiphytic, endophytic, and soil microbiota in the soil surrounding plants (Mello et al. 2011). The microbiota also includes bacteria (Bulgarelli et al. 2013). They compete for nutrients with pathogenic fungi, colonize wounds, and induce resistance (Mello et al. 2011). Yeasts, along with Bacillus spp. are increasingly being studied as tools that could be used in biological control plans (Punja and Utkhede 2003, Abraham et al. 2010, Janisiewicz et al. 2010, Machado and Bettiol 2010, Vargas et al. 2012, Kupper et al. 2013) and to induce plant resistance (Araujo and Menezes 2009, Zanardo et al. 2009, Bernardes et al. 2010). However, it is important to note that the use of yeasts and bacteria from the genus Bacillus to biologically control phytopathogens and/or induce plant resistance to phytopathogens can promote changes in their phytochemical composition.

Some studies have jointly cultivated plants with yeasts in vitro to increase the production of secondary metabolites, improve the production of phenolic compounds in Malus domestica and Curcuma mangga (Dias et al. 2016), and to increase the production of nicotine and serotonin in Nicotiana rustica (Karuppusamy 2009) (Table II).

Baenas et al. (2014) reported that elicitor treatments promoted defense responses in plants and may induce the synthesis of phytochemical compounds through primary metabolism and secondary metabolism. A yeast extract was included among the elicitor treatments because it has several components, such as chitin, $\mathrm{N}$-acetylglucosamine, $\beta$-glucan, glycopeptide, and ergosterol oligomers, that are capable of eliciting defense responses in plants.

Studies have shown that arbuscular mycorrhizal fungi (AMF) can induce the accumulation of carotenoids, phenolic compounds, anthocyanins, and tocopherol in lettuce (Lactuca sativa L.) leaves (Table II). They seem to be a viable and supplementary alternative that can be used to improve the nutritional quality of lettuce (Baslam and Goicoechea 2012, Baslam et al. 2013). The AMF increased plant growth without diluting the plant bioactive compound contents, which indicates that mycorrhizal symbiosis can potentially increase the levels of compounds with antioxidant activity without the need to increase lettuce intake in the diet (Baslam et al. 2013).

Giovannetti et al. (2015) reported similar results for AMF and tomatoes (Solanum lycopersicum L.). They reported that the lycopene 
TABLE II

Changes in plants bioactive and nutritional compounds by microrganisms.

\begin{tabular}{|c|c|c|c|c|}
\hline Plant & Eliciting agents & Compounds & Variation & Reference \\
\hline Malus domestica & $\begin{array}{c}\text { Yeast extract with Venturia } \\
\text { inaequalis }\end{array}$ & Phenolics compounds & Increase & \multirow[t]{2}{*}{ Dias et al. (2016) } \\
\hline Curcuma mangga & Yeast extract and chitosan & Phenolics compounds & Increase & \\
\hline Nicotiana rustica & $\begin{array}{l}\text { Yeast gene ornithine } \\
\text { decarboxylase }\end{array}$ & Nicotine and serotonin & Increase & $\begin{array}{l}\text { Karuppusamy } \\
\text { (2009) }\end{array}$ \\
\hline $\begin{array}{l}\text { Medicago } \\
\text { truncatula }\end{array}$ & Yeast extract & Isoflavone & Increase & \multirow[b]{2}{*}{ Saini et al. (2013) } \\
\hline $\begin{array}{l}\text { Glycyrrhiza } \\
\text { echinata }\end{array}$ & Yeast extract & $\begin{array}{c}\text { flavanone } 2 \text {-hydroxylase, } \\
\text { isoflavone } 2 \text { ž-hydroxylase and } \\
\text { isoflavone }\end{array}$ & Increase & \\
\hline Cucumis sativus & Yeast & $\mathrm{N}, \mathrm{P}, \mathrm{K}, \mathrm{Fe}, \mathrm{Zn}, \mathrm{Cu}, \mathrm{Mn}$ & Increase & $\begin{array}{l}\text { Shehata et al. } \\
\text { (2012) }\end{array}$ \\
\hline \multirow{3}{*}{ Allium sativum } & Saccharomyces cerevisiae & Organosulfur compounds & Increase & \multirow{3}{*}{ Kim et al. (2016) } \\
\hline & Lactobacillus plantarum & Organosulfur compounds & Increase & \\
\hline & Mimulus pilosus & Organosulfur compounds & Increase & \\
\hline Vitis vinífera & Botrytis cinerea & Resveratrol & Increase & $\begin{array}{l}\text { Jeandet et al. } \\
\qquad(1995)\end{array}$ \\
\hline $\begin{array}{l}\text { Lycopersicon } \\
\text { esculentum } \\
\text { L. esculentum and } \\
\text { Capsicum annum }\end{array}$ & $\begin{array}{c}\text { Polyversum } \AA(\text { Pythium } \\
\text { oligandrum }) \\
\text { Polyversum }{ }^{\circledR}(\text { Pythium } \\
\text { oligandrum })\end{array}$ & $\begin{array}{l}\text { Phenolic compounds and } \\
\text { carotenoids }\end{array}$ & Decrease & $\begin{array}{c}\text { Cwalina- } \\
\text { Ambroziak and } \\
\text { Amarowicz } \\
(2012)\end{array}$ \\
\hline $\begin{array}{c}\text { Solanum } \\
\text { lycopersicum }\end{array}$ & $\begin{array}{c}\text { Glomus intraradices } \\
\text { (arbuscular mycorrhizal fungus } \\
\text { - AMF) }\end{array}$ & $\begin{array}{l}\text { Lycopene } \\
\text { Ca, K, P and Zn }\end{array}$ & $\begin{array}{l}\text { Increase } \\
\text { Increase }\end{array}$ & $\begin{array}{l}\text { Giovannetti et al. } \\
\text { (2015) }\end{array}$ \\
\hline $\begin{array}{l}\text { Lactuca sativa var. } \\
\text { Capitata }\end{array}$ & $\begin{array}{l}\text { Glomus intraradices and } G \text {. } \\
\text { mosseae (AMF commercial) }\end{array}$ & $\begin{array}{l}\text { Phenolic compounds, } \\
\text { anthocyanins and total } \\
\text { carotenoids }\end{array}$ & Increase & $\begin{array}{l}\text { Baslam and } \\
\text { Goicoechea } \\
(2011)\end{array}$ \\
\hline $\begin{array}{l}\text { Lactuca sativa var. } \\
\text { Capitata }\end{array}$ & $\begin{array}{l}\text { Glomus intraradices and } G \text {. } \\
\text { mosseae (AMF commercial) } \\
\text { and G. fasciculatum (AMF) }\end{array}$ & $\begin{array}{l}\text { Neoxanthin, violaxanthin, } \\
\text { anteraxanthin, zeaxanthin, lutein } \\
\text { and } \beta \text {-carotene (carotenoids), } \\
\text { lactucaxanthin and tocopherol }\end{array}$ & Increase & $\begin{array}{l}\text { Baslam et al. } \\
\qquad(2013)\end{array}$ \\
\hline
\end{tabular}

content increased by $18.5 \%$ compared to the noninoculated control. Lycopene is a carotenoid and an important metabolite produced by tomato. It has high antioxidant activity and plays an essential role in disease prevention (Shami and Moreira 2004) (Table II). The AMF also increased the plant $\mathrm{Ca}, \mathrm{K}$, $\mathrm{P}$, and $\mathrm{Zn}$ contents, which improved the nutritional value of the fruits (Table II). These results suggest that AMF could have a large number of potential applications in sustainable food production systems. They could also be used to improve the ecological balance in the plant rhizosphere. This would reduce damage to the environment and could lead to increases in the production of high quality food (Giovannetti et al. 2015).

Kuhn and Pascholati (2010) investigated whether a biotic inducer (Bacillus cereus) and an abiotic inducer (acibenzolar-S-methyl) could improve common bean resistance against Xanthomonas axonopodis pv. Phaseoli. They observed that both inducers protected the plant against the phytopathogen, but the abiotic inducer 


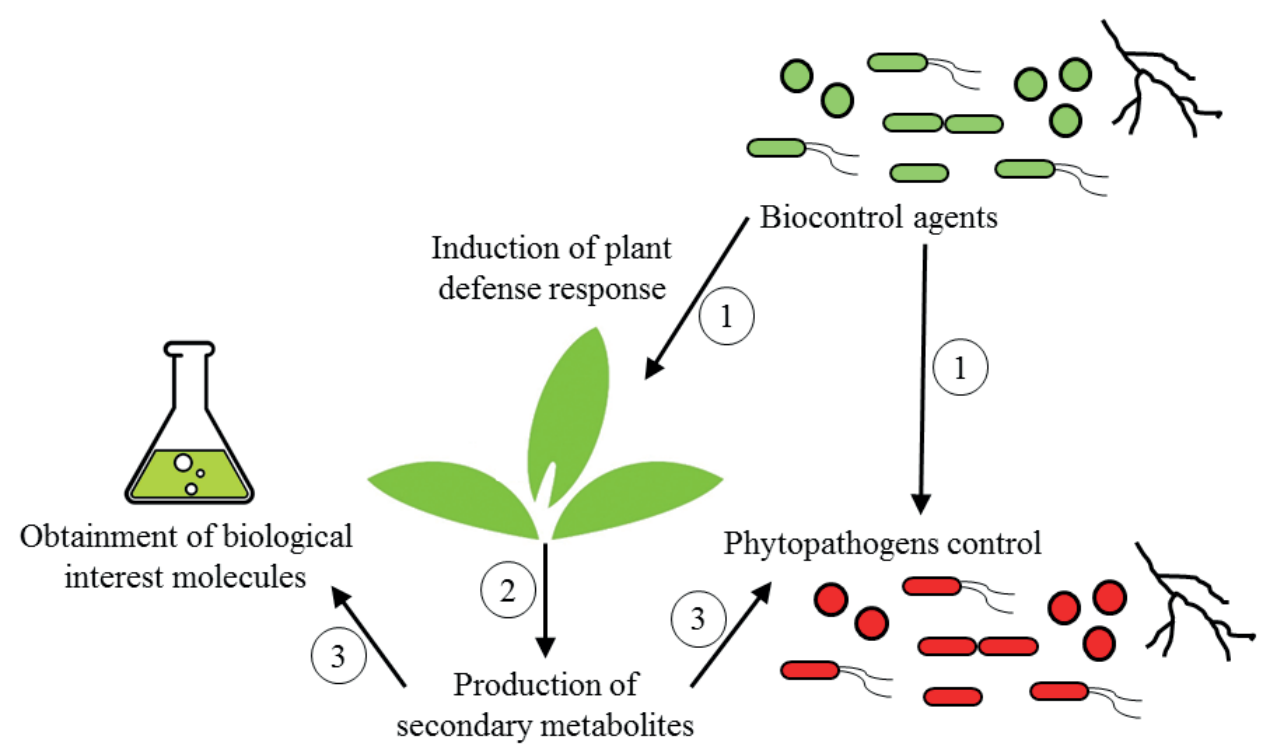

Figure 1 - Phytopathogens controls and obtaining secondary metabolites of interest through defense responses induction in the plant by biocontrol agents.

reduced the phenolic compounds content and the biomass of the plant, whereas the biotic inducer, the bacterium $B$. cereus, did not cause reductions in these parameters compared to the control.

Microorganisms can be used to fortify food. Kim et al. (2016) suggested fermenting garlic with the bacterium Lactobacillus plantarum, the filamentous fungus Mimulus pilosus, and the yeast Saccharomyces cerevisiae in an attempt to increase the contents of organosulfur compounds (Table II). These results suggest that there might be some compositional alterations when yeasts and bacteria are used to control A. rolfsii infection of garlic.

\section{PERSPECTIVES ON THE USE OF YEASTS AND Bacillus spp. TO CONTROL Athelia (Sclerotium) rolfsii IN Allium sativum}

Yeasts and Bacillus spp. are widely used to control several different phytopathogens. They have produced satisfactory results and commercial products are already available (Droby et al. 2002, Bettiol and Morandi 2009). The control of $A$. rolfsii in garlic is of great interest because this fungus causes considerable yield losses. Bacteria in the genus Bacillus are used to control A. rolfsii in other crops. Therefore it was important to investigate whether they could biologically control this phytopathogen in garlic. The Bacillus spp. and the yeasts use several mechanisms of action to control phytopathogens, which means that they could potentially control A. rolfsii, but further research on whether these species are suitable biocontrol agents needs to be undertaken.

Plants are able to defend themselves against potential pathogens using secondary metabolites. Their production is triggered by elicitor molecules or inducing agents. Secondary metabolites are molecules with an extensive range of biological activities, and are often of biological interest. Their resistance mechanisms include competition for nutrients, mycoparasitism, and antibiosis. Biocontrol agents can also act as elicitors. They induce defense responses in the host, such as the production of protective secondary metabolites (Punja and Utkhede 2003). Therefore biocontrol agents have considerable potential as disease control agents and many are also compounds of interest (Figure 1). These elicitor agents induce the 
production of secondary metabolites that could be potentially very valuable to the pharmaceutical and agricultural industries. Garlic is a plant that produces a wide range of molecules of biological interest that could increase the use of microorganisms with eliciting activity in biological control programs.

\section{REFERENCES}

ABOU-ALY HE, NEWEIGY NA, ZAGHLOUL RA, ELSAYED SA AND BAHLOUL AM. 2015. Evaluation of some biocontrol agents against soil pathogenic fungi. Res J Pharm Biol Chem Sci 6(1): 439-448.

ABRAHAM AO, LAING MD AND BOWER JP. 2010. Isolation and in vivo screening of yeast and Bacillus antagonists for the control of Penicillium digitatum of citrus fruit. Biol Control 53(1): 32-38.

AGRIANUAL. 2018. Anuário da agricultura Brasileira. IEG/ FNP. Agrobusiness intelligence, informe.

ALI A, JAVAID A AND SHOAIB A. 2017. GC-MS analysis and antifungal activity of methanolic root extract of Chenopodium album against Sclerotium rolfsii. Planta Daninha 35: 1-8.

ARAUJO FFD AND MENEZES D. 2009. Indução de resistência a doenças foliares em tomateiro por indutores biótico (Bacillus subtilis) e Abiótico (Acibenzolar-SMetil). Summa Phytopathol 35(3): 169-172.

BAENAS N, GARCÍA-VIGUERA C AND MORENO DA. 2014. Elicitation: A tool for enriching the bioactive composition of foods. Molecules 19(9): 13541-13563.

BASLAM M, ESTEBAN R, GARCÍA-PLAZAOLA JI AND GOICOECHEA N. 2013. Effectiveness of arbuscular mycorrhizal fungi (AMF) for inducing the accumulation of major carotenoids, chlorophylls and tocopherol in green and red leaf lettuces. Appl Microbiol Biotechnol 97(7): 3119-3128.

BASLAM M AND GOICOECHEA N. 2012. Water deficit improved the capacity of arbuscular mycorrhizal fungi (AMF) for inducing the accumulation of antioxidant compounds in lettuce leaves. Mycorrhiza 22(5): 347-359.

BERNARDES FS, PATRÍCIO FRA, SANTOS AS AND FREITAS SDS. 2010. Indução de resistência sistêmica por rizobactérias em cultivos hidropônicos. Summa Phytopathol 36(2): 115-121.

BETTIOL W AND MORANDI MA. 2009. Biocontrole de doenças de plantas: uso e perspectivas. Jaguariúna: Embrapa Meio Ambiente, 341 p.

BORLINGHAUS J, ALBRECHT F, GRUHLKE MC, NWACHUKWU ID AND SLUSARENKO AJ. 2014. Allicin: chemistry and biological properties. Molecules 19(8): 12591-12618.
BOUE SM, CLEVELAND TE, CARTER-WIENTJES C, SHIH BY, BHATNAGAR D, MCLACHLAN JM AND BUROW ME. 2009. Phytoalexin-enriched functional foods. J Agri Food Chem 57(7): 2614-2622.

BULGARELLI D, SCHLAEPPI K, SPAEPEN S, VAN THEMAAT EVL AND SCHULZE-LEFERT P. 2013. Structure and functions of the bacterial microbiota of plants. Ann Rev Plant Biol 64: 807-838.

CHAGAS FC, ZANETTI JF, DE OLIVEIRA VC AND DONATINI RS. 2012. Allium sativum L. na prevenção e tratamento de doenças cardiovasculares. Rev Biol Farm 7(2): 1-11.

CHAURASIA B, PANDEY A, PALNI LMS, TRIVEDI P, KUMAR B AND COLVIN N. 2005. Diffusible and volatile compounds produced by an antagonistic Bacillus subtilis strain cause structural deformations in pathogenic fungi in vitro. Microbiol Res 160(1): 75-81.

CHEN XH ET AL. 2007. Comparative analysis of the complete genome sequence of the plant growth-promoting bacterium Bacillus amyloliquefaciens FZB42. Nat Biotechnol 25(9): 1007-1014.

CHI M, LI G, LIU Y, LIU G, LI M, ZHANG X, SUN Z, SUI Y AND LIU J. 2015. Increase in antioxidant enzyme activity, stress tolerance and biocontrol efficacy of Pichia kudriavzevii with the transition from a yeast-like to biofilm morphology. Biol Control 90: 113-119.

CHOUDHARY DK AND JOHRI BN. 2009. Interactions of Bacillus spp. and plants-with special reference to induced systemic resistance (ISR). Microbiol Res 164(5): 493-513.

CORRALES-RAMÍREZ LC, CAYCEDO-LOZANO L, GÓMEZ-MÉNDEZ MA, RAMOS-ROJAS SJ AND RODRÍGUEZ-TORRES JN. 2017. Bacillus spp.: una alternativa para la promoción vegetal por dos caminos enzimáticos. Nova 15(27): 46-65.

CORZO-MARTÍNEZ M, CORZO N AND VILLAMIEL M. 2007. Biological properties of onions and garlic. Trends Food Sci Tech 18(12): 609-625.

CURTIS H, NOLL U, STÖRMANN J AND SLUSARENKO AJ. 2004. Broad-spectrum activity of the volatile phytoanticipin allicin in extracts of garlic (Allium sativum L.) against plant pathogenic bacteria, fungi and Oomycetes. Physiol Mol Plant Pathol 65(2): 79-89.

CWALINA-AMBROZIAK B AND AMAROWICZ R. 2012. Effects of biological and fungicidal environmental protection on chemical composition of tomato and red pepper fruits. Pol J Environ Stud 21(4): 831-836.

DALONSO N, IGNOWSKI E, MONTEIRO CMA, GELSEICHTER M, WAGNER TM, SILVEIRA MLL AND SILVA DAK. 2009. Extração e caracterização de carboidratos presentes no algo (Allium sativum L.): proposta de metodologia alternativa. Ciência e Tecnologia de Alimentos 29(4): 793-797. 
DANIA VO, FADINA OO, AYODELE M AND KUMAR PL. 2016. Evaluation of isolates of Trichoderma, Pseudomonas and Bacillus species as treatment for the control of postharvest fungal rot disease of yam (Dioscorea spp.). Arch Phytopathol Plant Protect 49(17-18): 456-470.

DE SOUSA TG AND BLUM LEB. 2013. Uso de Trichoderma harzianum e condicionador orgânico de solo para controle da podridão por Sclerotium rolfsii em alho. Biosci J 29(5): 1616-1623.

DI FRANCESCO A, MARI M, UGOLINI L AND BARALDI E. 2018. Effect of Aureobasidium pullulans strains against Botrytis cinerea on kiwifruit during storage and on fruit nutritional composition. Food Microbiol 72: 67-72.

DI FRANCESCO A, MILELLA F, MARI M AND ROBERTI R. 2017. A preliminary investigation into Aureobasidium pullulans as a potential biocontrol agent against Phytophthora infestans of tomato. Biol Control 114: 144149.

DIAS MI, SOUSA MJ, ALVES RC AND FERREIRA ICFR. 2016. Exploring plant tissue culture to improve the production of phenolic compounds: A review. Ind Crop Prod 82: 9-22.

DOMINGOS LB, BONTEMPO A AND LOPES EA. 2015. Podridão-branca do alho e da cebola. In: Visotto et al. (Eds), Avanços Tecnológicos Aplicados à Pesquisa na Produção Vegetal, Viçosa: Editora UFV, Minas Gerais, Brazil, p. 139-160.

DROBY S, VINOKUR V, WEISS B, COHEN L, DAUS A, GOLDSCHMIDT EE AND PORAT R. 2002. Induction of resistance to Penicillium digitatum in grapefruit by the yeast biocontrol agent Candida oleophila. Phytopathology 92(4): 393-399.

EL-NAGAR AAA, SABRY AM AND YASSIN MA. 2013. Virulence and Host Range of Sclerotium rolfsii and $S$. cepivorum. J Pure Appl Microbiol 7(3): 1693-1705.

FAGUNDES MH. 2016. Conjuntura Especial - Setembro 2016 Alho, Companhia Nacional de Abastecimento - Conab.

FARIA FA, BUENO CJ AND PAPA MDFS. 2009. Fungitoxic activity of Momordica charantia L. to control of Sclerotium rolsii Sacc. Acta Scient Agro 31(3): 383-389.

FIGUEREDO MS, TONELLI ML, IBÁÑEZ F, MORLA F, CERIONI G, DEL CARMEN TORDABLE M AND FABRA A. 2017. Induced systemic resistance and symbiotic performance of peanut plants challenged with fungal pathogens and co-inoculated with the biocontrol agent Bacillus sp. CHEP5 and Bradyrhizobium sp. SEMIA6144. Microbiol Res 197: 65-73.

GIOVANNETTI M ET AL. 2015. Selenium fertilization and mycorrhizal technology may interfere in enhancing bioactive compounds in edible tissues of lettuces. Scien Horticulturae 195: 163-172.
GÓMEZ LG AND SÁNCHEZ-MUNIZ FS. 2000. Revisión: Efectos cardiovasculares del ajo (Allium sativum). Arch Latinoam Nutr 50(3): 219-229.

GOND SK, BERGEN MS, TORRES MS AND WHITE JR JF. 2015. Endophytic Bacillus spp. produce antifungal lipopeptides and induce host defence gene expression in maize. Microbiol Res 172: 79-87.

HIRPARA DG, GAJERA HP, HIRPARA HZ AND GOLAKIYA BA. 2016. Molecular diversity and fingerprints of Trichoderma associated with antagonistic potentials against Sclerotium rolfsii Sacc. J Plant Dis Prot 124(1): 31-40.

HIRPARA DG, GAJERA HP, HIRPARA HZ AND GOLAKIYA BA. 2017. Antipathy of Trichoderma against Sclerotium rolfsii Sacc.: Evaluation of Cell Wall-Degrading Enzymatic Activities and Molecular Diversity Analysis of Antagonists. J Mol Microbiol Biotechnol 27(1): 22-28.

HUANG X, ZHANG N, YONG X, YANG X AND SHEN Q. 2012. Biocontrol of Rhizoctonia solani damping-off disease in cucumber with Bacillus pumilus SQR-N43. Microbiol Res 167(3): 135-143.

IBGE. 2016. Levantamento Sistemático da Produção Agrícola - Pesquisa Mensal de Previsão e Acompanhamento das Safras Agrícolas no Ano Civil, Rio de Janeiro 29(12): 1-82.

ISAIAS CO, MARTINS I, SILVA JBT, SILVAJPAND MELLO SCM. 2014. Ação antagônica e de metabólitos bioativos de Trichoderma spp. contra os patógenos Sclerotium rolfsii e Verticillium dahliae. Summa Phytopathol 40(1): 34-41.

ISLAM MM, HOSSAIN DM, NONAKA M AND HARADA N. 2017. Biological control of tomato collar rot induced by Sclerotium rolfsii using Trichoderma species isolated in Bangladesh. Arch Phytopathol Plant Protection 50(3-4): 109-116.

JANAHIRAMAN V, ANANDHAM R, KWON SW, SUNDARAM S, KARTHIK PANDI V, KRISHNAMOORTHY R, KIM K, SAMADDAR S AND AS T. 2016. Control of wilt and rot pathogens of tomato by antagonistic pink pigmented facultative methylotrophic Delftia lacustris and Bacillus spp. Front Plant Sci 7: 1-11.

JANISIEWICZ WJ, KURTZMAN CP AND BUYER JS. 2010. Yeasts associated with nectarines and their potential for biological control of brown rot. Yeast 27: 389-398.

JEANDET P, BESSIS R, SBAGHI M AND MEUNIER P. 1995. Production of the phytoalexin resveratrol by grapes as a response to Botrytis attack under natural conditions. $\mathrm{J}$ Phytopathol 143(3): 135-139.

JIMENEZ-GARCIA SN, VAZQUEZ-CRUZ MA, GUEVARA-GONZALEZ RG, TORRES-PACHECO I, CRUZ-HERNANDEZ A AND FEREGRINO-PEREZ AA. 2013. Current approaches for enhanced expression of secondary metabolites as bioactive compounds in plants for agronomic and human health purposes - A review. Pol J Food Nutr Sci 63(2): 67-78. 
JOHN NS, ANJANADEVI IP, NATH VS, SANKAR SA, JEEVA ML, JOHN KS AND MISRA RS. 2015. Characterization of Trichoderma isolates against Sclerotium rolfsii, the collar rot pathogen of Amorphophallus-A polyphasic approach. Biol Control 90: 164-172.

KARUPPUSAMY S. 2009. A review on trends in production of secondary metabolites from higher plants by in vitro tissue, organ and cell cultures. J Med Plants Res 3(13): 1222-1239.

KIM S, PARK SL, LEE S, LEE SY, KO S AND YOO M. 2016. UPLC/ESI-MS/MS analysis of compositional changes for organosulfur compounds in garlic (Allium sativum L.) during fermentation. Food Chem 211: 555-559.

KLEIN MN AND KUPPER KC. 2018. Biofilm production by Aureobasidium pullulans improves biocontrol against sour rot in citrus. Food Microbiol 69: 1-10.

KOTASTHANE AS, AGRAWAL T, ZAIDI NW AND SINGH US. 2017. Identification of siderophore producing and cynogenic fluorescent Pseudomonas and a simple confrontation assay to identify potential bio-control agent for collar rot of chickpea. 3 Biotech 7(2): 137.

KUHN OJ AND PASCHOLATI SF. 2010. Custo adaptativo da indução de resistência em feijoeiro mediada pela rizobactéria Bacillus cereus ou acibenzolar-S-metil: atividade de enzimas, síntese de fenóis e lignina e biomassa. Summa Phytopathol 36(2): 107-114.

KUMAR P, DUBEY RC AND MAHESHWARI DK. 2012. Bacillus strains isolated from rhizosphere showed plant growth promoting and antagonistic activity against phytopathogens. Microbiol Res 167(8): 493-499.

KUMAR PN, SWAPNA TH, KHAN MY, REDDY G AND HAMEEDA B. 2015. Statistical optimization of antifungal iturin A production from Bacillus amyloliquefaciens RHNK22 using agro-industrial wastes. Saude J Biol Sci 24: $1722-1740$.

KUPPER KC, CERVANTES ALL, KLEIN MN AND DA SILVA AC. 2013. Avaliação de microrganismos antagônicos, Saccharomyces cerevisiae e Bacillus subtilis para o controle de Penicillium digitatum. Rev Bras Frutic 35(2): 425-436.

KUSANO M, KOBAYASHI M, IIZUKA Y, FUKUSHIMA A AND SAITO K. 2016. Unbiased profiling of volatile organic compounds in the headspace of Allium plants using an in-tube extraction device. BMC Res Notes 9(1): 133.

KWON J. 2010. Stem rot of garlic (Allium sativum) caused by Sclerotium rolfsii. Mycobiology 38(2): 156-158.

LANNA FILHO R, FERRO HM AND DE PINHO RSC. 2010. Controle biológico mediado por Bacillus subtilis. R Trópica: Ciênc Agr Biológicas 4(2): 12-20.

LANZOTTI V. 2006. The analysis of onion and garlic. J chromatgr A 1112(1): 3-22.
LATTANZIO V, LATTANZIO VM AND CARDINALI A. 2006. Role of phenolics in the resistance mechanisms of plants against fungal pathogens and insects. Phytochemistry: Advances in research 661: 23-67.

LI Y, HE F, LAI H AND XUE Q. 2017. Mechanism of in vitro antagonism of phytopathogenic Sclerotium rolfsii by actinomycetes. Eur J Plant Pathol 149(2): 299-311.

LONDHE VP, GAVASANE AT, NIPATE SS, BANDAWANE DD AND CHAUDHARI PD. 2011. Role of garlic (Allium sativum) in various diseases: an overview. J Pharma Research and Opinion 1(4): 129-134.

MACHADO MADCF AND BETTIOL W. 2010. Potencial para o biocontrole de Botrytis cinerea por leveduras em sistema integrado de cultivo de lírio. Pesq Agropec Brasileira 45(6): 539-545.

MARQUES MC. 2017. Alho, Companhia Nacional de Abastecimento - Conab.

MELLO MRF, SILVEIRA EB, VIANA IO, GUERRA ML AND MARIANO RLR. 2011. Uso de antibióticos e leveduras para controle da podridão-mole em couvechinesa. Hortic Brasileira 29: 78-83.

MNIF I, GRAU-CAMPISTANY A, CORONEL-LEÓN J, HAMMAMI I, TRIKI MA, MANRESA A AND GHRIBI D. 2016. Purification and identification of Bacillus subtilis SPB1 lipopeptide biosurfactant exhibiting antifungal activity against Rhizoctonia bataticola and Rhizoctonia solani. Environ Sci Pollut Res 23(7): 6690-6699.

MOROZINI JF, GUTH SC, PINTO MM, THEODORO AJ AND OLINQUEVITCH JL. 2005. A Viabilidade econômica do plantio do alho. In: Anais do Congresso Brasileiro de Custos-ABC, 2005.

MOURA AP, GUIMARÃES JA, FERNANDES FR AND MICHEREFF FILHO M. 2013. Recomendações técnicas para o manejo integrado de pragas da cultura do alho. Circular Técnica 118, Brasília: Embrapa Hortaliças, 12 p.

OTA CCC, DA SILVA DVG, JACON KC, BAURA V AND NUNES S. 2010. Avaliação da atividade antimicrobiana e anti-inflamatória do extrato hidroalcoólico do Allium sativum (alho). Tuiuti: Ciência e Cultura 43: 37-49.

PACHECO KR, VISCARDI BSM, DE VASCONCELOS TMM, MOREIRA GAM, DO VALE HMM AND BLUM LEB. 2016. Efficacy of Trichoderma asperellum, T. harzianum, T. longibrachiatum e $T$. reesei against Sclerotium rolfsii. Biosci J 32(2): 412-421.

PELZER GQ, HALFELD-VIEIRA BA, NECHET KDL, DE SOUZA GR, ZILLI JE AND PERIN L. 2011. Mecanismos de controle da murcha-de-esclerócio e promoção de crescimento em tomateiro mediados por rizobactérias. Trop Plant Pathol 36(2): 95-103.

PONTIN M, BOTTINI R, BURBA JL AND PICCOLI P. 2015. Allium sativum produces terpenes with fungistatic properties in response to infection with Sclerotium cepivorum. Phytochemistry 115: 152-160. 
PUNJA ZK AND UTKHEDE RS. 2003. Using fungi and yeasts to manage vegetable crop diseases. TRENDS in Biotechnology 21(9): 400-407.

RAO KM, RAJU KS AND RAVISANKAR H. 2015. Antifungal properties of native Trichoderma isolates against Sclerotium rolfsii and Pythium aphanidermatum infecting tobacco. Journal Environ Biol 36(6): 1349-1353.

RESENDE FV, HABER LL AND PINHEIRO JB. A Cultura do Alho. EMBRAPA. Disponível em: <https://www. embrapa.br/documents/1355126/9124396/Sistema+de+ Produ\%C3\%A7\%C3\%A3o+de+Alho/64258d94-6bb84826-a0e9-ece47aa434ff $>$. Acesso em: 04 de Dezembro de 2016.

SAINI RK, AKITHADEVI MK, GIRIDHAR P AND RAVISHANKAR GA. 2013. Augmentation of major isoflavones in Glycine $\max \mathrm{L}$. through the elicitormediated approach. Acta Bot Croat 72(2): 311-322.

SARITHA B, PANNEERSELVAM P AND GANESHAMURTHY AN. 2015. Antagonistic potential of mycorrhiza associated Pseudomonas putida against soil borne fungal pathogens. Plant Archives 15(2): 763-768.

SHAMI NJIE AND MOREIRA EAM. 2004. Licopeno como agente antioxidante. Rev Nutr 17(2): 227-236.

SHANKAR S, SINGH G AND SRIVASTAVA RK. 2007. Chemoprevention by resveratrol: molecular mechanisms and therapeutic potential. Front in bioscience: a Journal and Virtual Library 12: 4839-4854.

SHEHATA SA, FAWZY ZF AND EL-RAMADY HR. 2012. Response of cucumber plants to foliar application of chitosan and yeast under greenhouse conditions. Aust J Basic Appl Sci 6(4): 63-71.

SHETTY K AND WAHLQVIST M. 2004. A model for the role of the proline-linked pentosephosphate pathway in phenolic phytochemical biosynthesis and mechanism of action for human health and environmental applications. Asia Pac J Clin Nutr 13(1): 1-24.

SLUSARENKO AJ, PATEL A AND PORTZ D. 2008. Control of plant diseases by natural products: Allicin from garlic as a case study. Eur J Plant Pathol 121(3): 313-322.
SOUZA RJ AND MACÊDO FS. 2009 Cultura do Alho: tecnologias modernas de produção. $1^{\text {a }}$ ed., Lavras: Editora UFLA, Minas Gerais, Brasil, 181 p.

SUN C, LIN M, FU D, YANG J, HUANG Y, ZHENG X AND YU T. 2018. Yeast cell wall induces disease resistance against Penicillium expansum in pear fruit and the possible mechanisms involved. Food Chem 241: 301-307.

SUNEETA P, AIYANATHAN K AND NAKKEERAN S. 2016. Efficacy of Bacillus spp. in the management of collar rot of Gerbera under protected cultivation. Research on Crops 17(4): 745-752.

THAMPI A AND BHAI RS. 2017. Rhizosphere actinobacteria for combating Phytophthora capsici and Sclerotium rolfsii, the major soil borne pathogens of black pepper (Piper nigrum L.). Biol Control 109: 1-13.

ÚBEDA JF, MALDONADO M, BRIONES AI AND GONZÁLEZ FJ. 2014. Bio-prospecting of distillery yeasts as bio-control and bio-remediation agents. Curr Microbiol 68(5): 594-602.

VAJA KN, GAJERA HP, HIRPARA DG, VAJA VN AND GOLAKIYA BA. 2016. Biochemical characterization and molecular identification of Pseudomonas antagonists inhibiting Fusarium oxysporum f. sp. ciceri and Sclerotium rolfsii Sacc. I J of Agric Biochemistry 29(2): 175-183.

VARGAS M, GARRIDO F, ZAPATA N AND TAPIA M. 2012. Isolation and selection of epiphytic yeast for biocontrol of Botrytis cinerea Pers. on table grapes. Chil J Agr Res 72(3): 332-337.

YEH YY AND LIU L. 2001. Cholesterol-lowering effect of garlic extracts and organosulfur compounds: human and animal studies. J Nutr 131(3): 989S-993S.

ZANARDO NMT, PASCHOLATI SF AND FIALHO MB. 2009. Resistência de plântulas de pepineiro a Colletotrichum lagenarium induzida por frações de extrato de Saccharomyces cerevisiae. Pesq Agropec Bras 44(11): 1499-1503.

ZHANG J, XIE J, ZHOU Y, DENG L, YAO S AND ZENG K. (2017). Inhibitory effect of Pichia membranaefaciens and Kloeckera apiculata against Monilinia fructicola and their biocontrol ability of brown rot in postharvest plum. Biol Control 114: 51-58. 